\title{
World City?
}

\author{
SHIRLEY FITZGERALD
}

W

hen I began to study Australian history the idea that there was anything worth saying about our cities, in a theoretical sense, was only just beginning to gain traction. There were works of what is called 'local history' about particular places, but back then a theorised study of the urban condition did not loom large in Australian historiography. Certainly in my undergraduate years in the 1960s the debates and flash points in Australian history did not include any conscious focus on cities as discrete sites of discourse.

The shift to a focus on urban history came from two directions. The first was the work of conventional economic historians who progressed our understanding of the important role cities played in overall capital accumulation and as sites for foreign investment. The most significant was Noel Butlin's Investment in Australian Economic Development 1861$1891 .{ }^{1}$

This was not bedtime reading. But its message got through and became enormously influential in turning our focus towards urban 
studies. Butlin's message, at the risk of gross simplification, was that investment into the economy of eastern Australia went into three more or less equal sectors: a third to rural industries, primarily the pastoral industry, a third to transport, especially railways, and a third into creating the infrastructure of the cities. We all knew about the pastoral industry and the topic of transport, especially railway development was well worked. But cities? This was exciting.

A second reason for the growth of interest in urban history in the 1970s was the 1970s themselves. We all had our own trajectory into the study of Sydney. Mine was tied up with discovering the city new after growing up and attending university in Adelaide. Sydney, I discovered, was a different place.

On Sunday evenings at the Wayside Chapel at Kings Cross there were wild discussions led by people like geneticist and population guru Charles Birch (1918-2009), Tom Uren (1921-) whose understanding of urban issues was eventually channelled into the Whitlam Government's Department of Urban and Regional Development and even John Webster (1913-2008). Known simply as Webster, he would turn up on Sunday evening after an afternoon of spruiking his mixture of anarchist wisdom and nonsense at the Sunday Domain Speakers Corner.

Bill Crews, who runs the Exodus Foundation at Ashfield, was then organising a program of visiting the elderly in the Kings Cross Darlinghurst area. I volunteered for this and soon learned that while I might have little to give to these people except company and a listening ear, it was a way into a rich load of stories and memories of the city that I would otherwise have not been keyed into. Getting involved, too, in the Wayside Chapel's Redfern breakfast program opened up a whole other window on the city. Discovering the huge ring of nineteenth-century residential and industrial suburbs around Sydney's original core was new and exciting in the questions it threw up. I was reading history but I was also starting to learn to look at place. All places are different and this one was getting under my skin.

A lot of my work has focused on the realities of the class and social divisions of the late nineteenth century. And the writers who were influencing me included the1970s work of Spanish sociologist Manuel Castells and American geographer David Harvey. ${ }^{2}$ Both these scholars have since garnered long lists of publications. There was also the New York urban activist Jane Jacobs who popularised the field and focused the minds of many on the kinds of issues they were writing about. ${ }^{3}$ I was keen to debunk the easy assumptions of a new and fairer society that was too easily labelled the workers' paradise and I was determined to establish that Sydney was nothing other than a new world version of the 
same old capitalist society it had sprung from, replicating old inequalities and inequities. By denying its industrial heart, and even its very existence in this supposed pastoral and agricultural place, Sydney was, by the end of the nineteenth century, as unequal socially and as environmentally challenged as older British cities.

Looking back on my work now it is plain that it was undertaken by someone who thought that she was living in a place that had moved on from there, and was, by the 1970s, indeed a fairer place. Then slowly over the next thirty years inequality was back with a vengeance, gains hard fought were wound back and all the old terror were returning. This is starkly so if we stand back and take a global look at the urbanising process. Mike Davis, in his Planet of Slums, sets out in terrifying detail the stupendous growth of mega slums that have emerged 'when shanty towns and squatter communities merge in continuous belts of informal housing and poverty, usually on the urban periphery.' He claims for the five great metropolises of South Asia - Karachi, Mumbai, Delhi Kolkata and Dhaka - 15,000 slum districts with a total population of over 20 million. And while a few of the currently exploding slums have a long history, the vast majority of them have emerged since the 1960s. Their growth rates have been astonishing and their presence has turned much urban theory on its head. ${ }^{4}$

The inner city slums of nineteenth-century European cities were populated by people who were primarily enmeshed within the urban economy to which they contributed much needed labour for which they were inadequately remunerated. The favelas and shanty towns of South America, South Asia, Africa and the Middle East are populated by people who live outside the formal economy. The Victorian's fear of the eruptive potential of their poor was calmed in the twentieth century by the gradual improvement in living standards and inclusion of the poor into the mainstream of cultural and social production. The work of Davis and others raises again the spectre of social collapse.

With some exceptions such places are of course unplanned. City plans have long fascinated me as the plan, the layout, the accessibility or inaccessibility of infrastructure has ramifications for communities and for the cultural and intellectual life of each city's inhabitants. Who gets access to scarce urban land in Sydney is the question that continues to fascinate. But lately I've begun to focus on the different ways that other societies have organised urban space for the clarity this can provide for some of our own ongoing urban issues. 


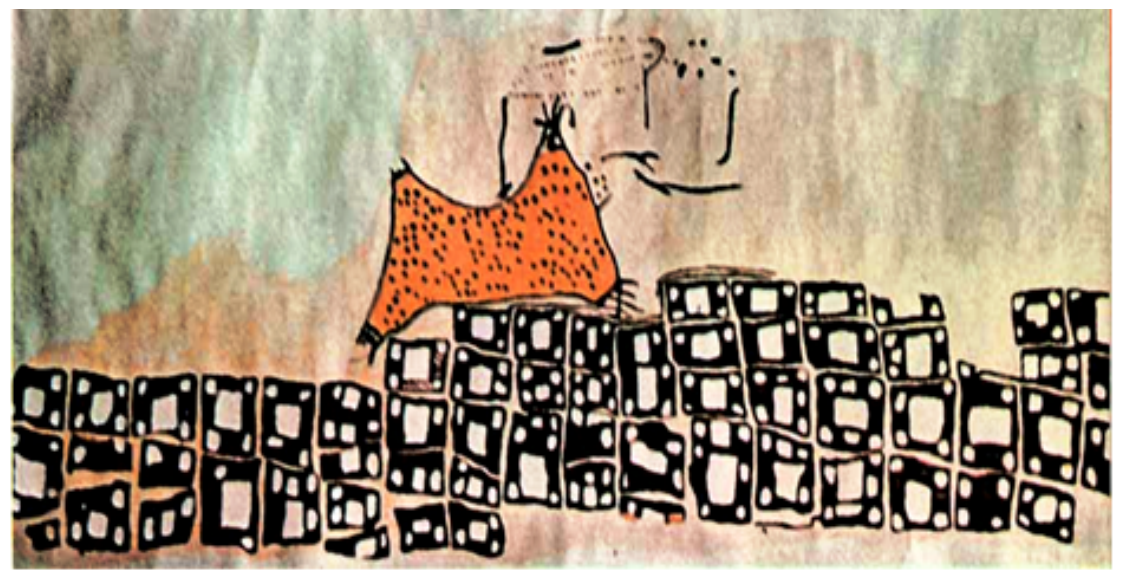

Figure 1 A diagrammatic representation of the original plan of Catal-Huyuk found on a wall in a shrine, Museum of Anatolian Civilization, Ankara, Turkey (Photographer Shirley Fitzgerald)

The Museum of Anatolian Civilization in Ankara is housed in a lovely old Ottoman storage building, stuffed full of wonderful antiquities dripping with gold and silver. Amidst this usual overload of wonders there is a small painting of a city plan found on a wall in a shrine in Catal-Huyuk.

This place is often claimed as the first planned city of the first great prehistoric civilization. The plan is carbon dated to about $6500 \mathrm{BC}$. How much before that it existed a place is unclear. Not much of the city is left. It's a neolithic site, a 32-acre mound, mostly unexcavated. It is believed to have had a population of about 6000 , making it the most concentrated place of human habitation at the time. Seeing this plan was a moment of epiphany for me. We tend to imagine that urban places are permanent when of course they are complex, fragile and transitory. In Catal-Huyuk you had to walk through the houses of others to arrive at your own. It was a timid protective urban layout designed to keep maunderers at bay in an uncivilised world.

Moving on temporally we could consider the medieval Islamic city of Fez in Morocco with its narrow streets lined with windowless houses where heavy doors open onto internal courtyards, workshops, bakeries, schools and so on, all hidden from view and protected from invasion. As the safety of the city came to be taken for granted, the buildings opened more onto the street, although the internal courtyard and living space remain features of many cities up to the nineteenth century. The long length of city blocks in parts of European cities like Berlin only 


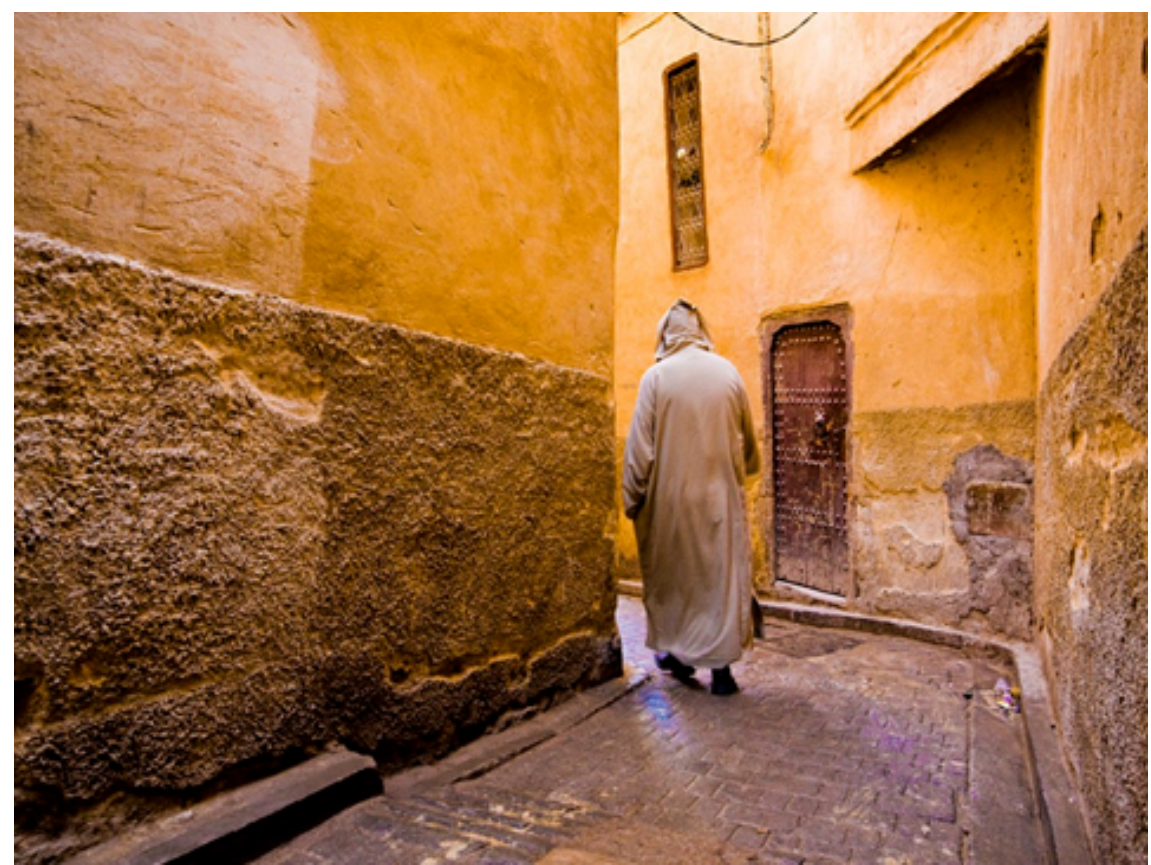

Figure 2 Narrow streets with blank exterior walls, Fez, Morocco (Photographer Shirley Fitzgerald)

become readable when the internal spaces are revealed. Finally houses became free standing, outward looking and hemmed around with fences that defined a private territory and maintained distance between atomised living groups.

The point of these images is to show the trajectory in urban form from huddled common spaces to ever more atomised units of habitation devoid of communal focus. From cities where people walked and worked in confined areas to cities with enormous footprints where nothing can occur without the injection of huge amounts of transport infrastructure.

What makes for a civilised society? Many claim that atomised houses and monster freeways do not achieve it. These issues have been constantly talked about in Sydney since at least the 1960s. Learned papers contemplate the post suburban terrain, ${ }^{5}$ while politicians still sanction freeway construction. Today new understandings of the imperative for sustainability only make the issues more pressing. John McInerney, City Planner for Melbourne, then for Sydney, once put it to me that a civilised society would decide how much of its precious urban ground it wants to give over to roads and then stick to it. Imagine that. 


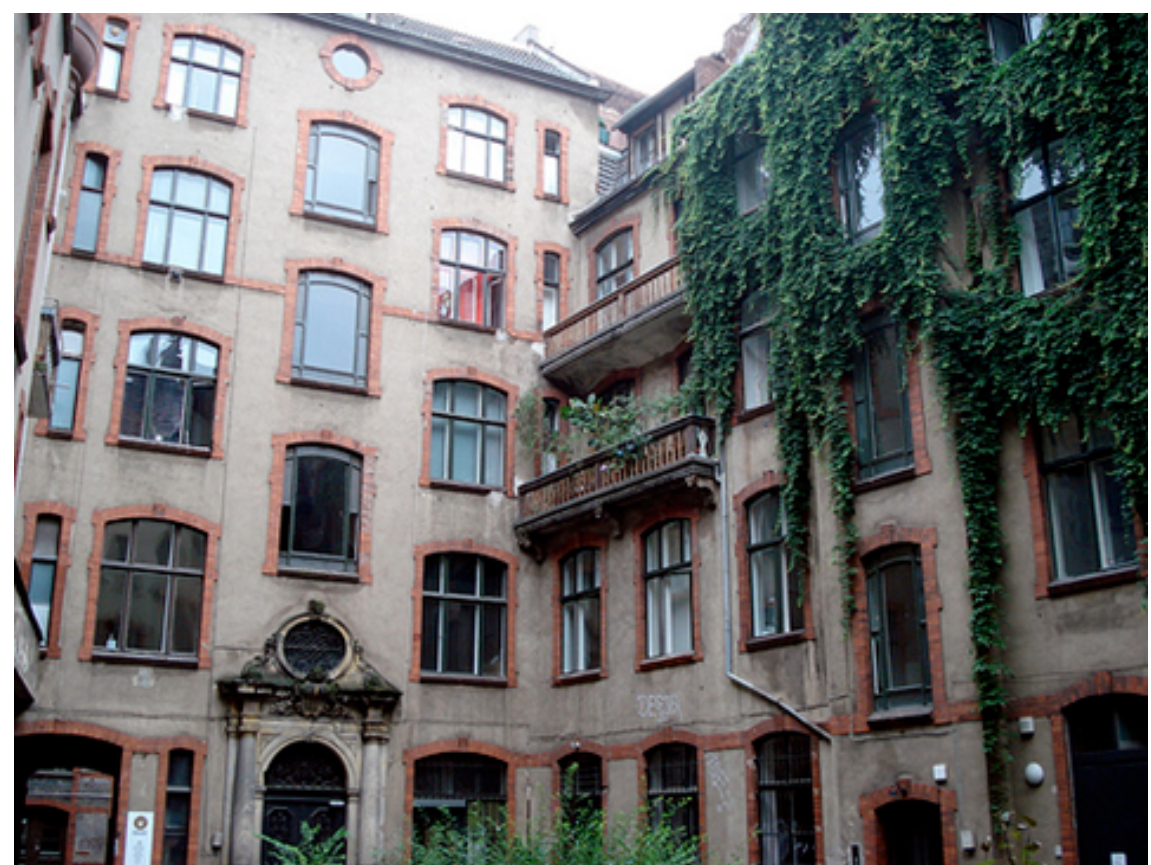

Figure 3 Internal space, Berlin courtyard (Photographer Shirley Fitzgerald)

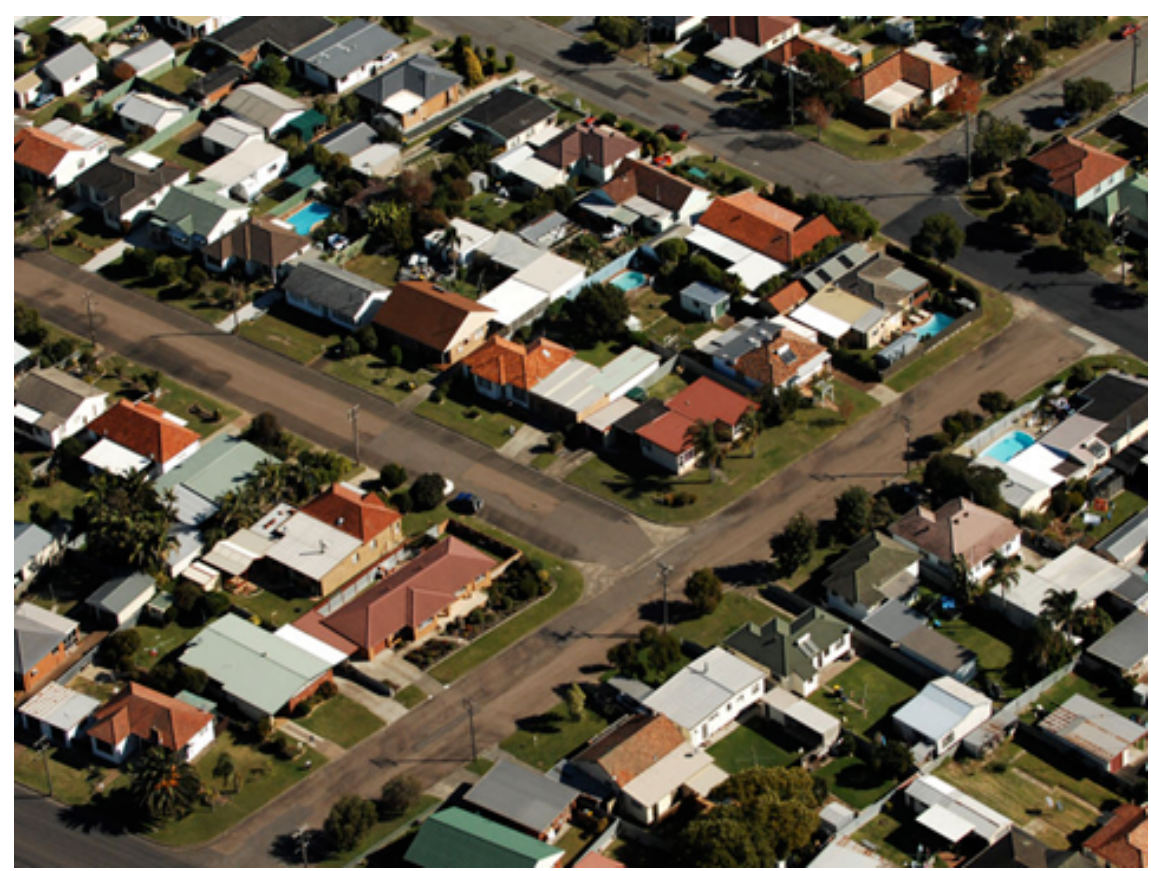

Figure 4 Sprawl, any Australian city suburb (Photograph Shirley Fitzgerald) 


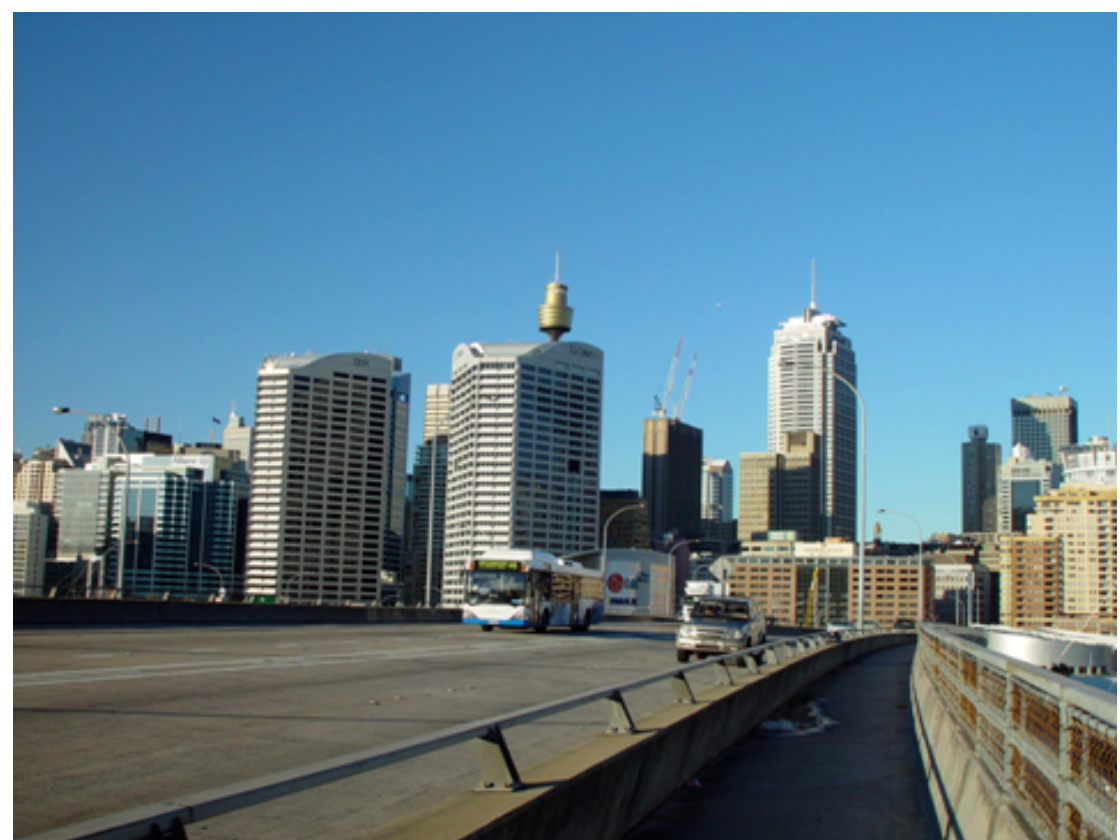

Figure 5 The road from my place to the city (Photographer Shirley Fitzgerald)

This is more or less what Jane Jacobs said to Robert Moses in New York in the 1960s and what lots of people have been saying ever since. If Butlin showed us the presence of the city in the Australian landscape, then Castells and Harvey showed why it was worth worrying about how all the pieces of that landscape get used. Recently I attended an architecture forum at the University of Sydney where a distinguished US professor gave a paper about making Los Angeles more 'human' by encouraging small scale interventions like local markets and community gardens. That is fine. These may be good little things to do. But when someone suggested that this kind of thing wasn't really addressing the big issues of mal-distribution of wealth and of access to scarce urban resources and amenities and that perhaps today's students should go back and read the social justice literature of people such as David Harvey, the speaker was dismissive. This was all old hat.

Historians should understand old hats. And if they are now thought shabby, perhaps we need to revisit some of them and put them back on the modelling block to reshape them for today. There is one thing you learn with time. History has to be done over again and again to keep us all civilised, creative and new. 
Sydney Journal | Fitzgerald

Shirley Fitzgerald is Adjunct Professor of History at the Australian centre for Public History at the University of Technology, Sydney and formerly City Historian for the Sydney City Council

\section{ENDNOTES}

${ }^{1}$ Noel Butlin, Investment in Australian Economic Development, 1861-1891, Cambridge University Press, 1964.

${ }^{2}$ Manuel Castells, The Urban Question, 1972, English translation, Edward Arnold, London, 1977; David Harvey, Social Justice and the City, John Hopkins UP, Baltimore, 1973; City, Class and Power, London 1978.

${ }^{3}$ Jane Jacobs, The Economy of Cities, Random House, New York, 1969.

${ }^{4}$ Mike Davies, Planet of Slums, Verso, London, 2006, pp26, 27.

${ }^{5}$ Kay Anderson, et al (eds), 'After Sprawl: Post Suburban Sydney', conference Eproceedings, Centre for Cultural Research, University of Western Sydney, 2006. 